\title{
artigos
}

DOI: 10.11606/issn.2318-8855.v6i6p105-124

\section{As formas de escravização presentes na Lei das Doze Tábuas (Século V a.C.)}

Ana Carolina Sodré Ferreira*

Resumo: O presente artigo buscou analisar as formas de escravização existentes no século $V$ a.C. na sociedade romana a partir da análise da Lei das Doze Tábuas e do contexto social do início da república, objetivando identificar finalidades não-econômicas no processo de escravização durante este século. Para atingir este objetivo, o artigo baseou-se na teoria de Keith R. Bradley de que, em um primeiro momento, a escravidão na sociedade romana não era majoritária nem possuía fins exclusivamente econômicos. Na primeira parte do artigo, foi levantado um debate historiográfico sobre a visão geral da escravidão romana; na segunda parte, discorreu-se sobre os conflitos entre plebeus e patrícios no período arcaico, destacando suas motivações, reivindicações e características gerais; em um terceiro momento, foi realizada a análise de três passagens da Lei das Doze Tábuas, sendo identificadas três formas de escravização provenientes dos direitos paterno, jurídico e financeiro. Por fim, nas considerações finais, foi argumentado que a Lei das Doze Tábuas apesar de ter sido uma conquista da plebe, não favoreceu esta, pois continuou a beneficiar os patrícios e a manter a escravidão por dívidas; no que se refere a escravidão, o contexto da época e a ausência de uma regulamentação da escravidão na Lei das Doze Tábuas, sugerem que a escravização no século $\checkmark$ a.C. não possuía finalidades exclusivamente econômicas, perpassando, também, por interesses políticos e sociais.

Palavras-chave: escravidão romana; formas de escravização; República romana.

\section{Introdução}

A escravidão romana caracterizou-se por manifestar diversas formas de organizações e finalidades. A escravidão durante o período republicano (509-31 a.C.), por exemplo, adquiriu

\footnotetext{
* Possui graduação em andamento no curso de História da Faculdade de Filosofia Letras e Ciências Humanas da Universidade de São Paulo. Email para contato: ana.sodre.ferreira@usp.br.
} 


\section{artigos}

Ana Carolina Sodré Ferreira

diferentes facetas em seus diferentes momentos ao longo do tempo, tendo sido moldada a partir de elementos internos e externos. Não obstante, Joly (2006) acredita que a escravidão durante o Império Romano não tenha sido predominante e, sim, mais uma das formas de trabalho compulsório existentes naquela época:

Têm-se questionado a predominância da escravidão no Império Romano como um todo, apontando para a sua restrição a determinadas áreas geográficas, em coexistência com outras modalidades de trabalho compulsório. (JOLY, 2006, p. $68)$.

No que tange aos fatores externos, a conquista de novos territórios significou a aquisição de riquezas e prisioneiros de guerra, além da expansão territorial requisitar o aumento de indivíduos que pudessem trabalhar nas terras, seja nos campos e cidades, seja no interior das grandes propriedades. Com a intensificação do desenvolvimento das atividades comerciais, a economia adquiriu uma nova complexidade, favorecendo, inclusive, o desenvolvimento urbano.

Com a expansão romana na e além da Península Itálica, o número de territórios conquistados elevou-se significativamente, bem como o número de escravos e de recursos naturais, principalmente minérios. De fato, as guerras travadas e o aumento de escravos sempre foram elementos proporcionais (GARRAFFONI, 2008). De acordo com Garraffoni (2008), o aumento de escravos implicou na utilização da mão de obra escrava em diferentes funções, "seja no campo, nas oficinas ou nas casas dos membros das elites" (GARRAFFONI, 2008, p. 57).

Até o século III a.C., a maioria dos escravos se encontravam concentrados no âmbito doméstico (escravos domésticos) (FUNARI, 2003); após, observa-se uma constante presença de escravos em diferentes setores da economia romana. Joly (2005) elenca alguns desses diversificados trabalhos, a saber: trabalhos com função de gestão, como o de tesoureiro e de comando de lojas ou oficinas pertencentes ao senhor; administração das finanças do senhor; trabalhos relacionados ao comércio, podendo o escravo atuar, inclusive, como intermediário ou procurador de seu senhor em transações comerciais e financeiras. 


\section{artigos}

As formas de escravização presentes na Lei das Doze Tábuas (Século V a.C.)

Consequentemente, essa diversificação de funções destinadas aos escravos estabeleceu uma hierarquia e rivalidade entre estes na quais poderiam ocorrer a disputa pelas melhores funções a serem exercidas e pela maior aproximação junto ao senhor, que implicava na conquista de confiança e "afeto" deste. Para Finley (1991), em razão desta hierarquização de funções entre os escravos, e as consequentes inimizades originadas desta situação, estes não teriam formado uma classe - como determina a intepretação marxista -, sendo, portanto, a condição de escravizado definida jurídica e politicamente, à exemplo de leis que garantiam a escravização em situações de dívidas, delitos e direitos. Ainda neste raciocínio, o autor questiona, também, a abordagem marxista em relação à escravidão romana, que enfatiza uma abordagem econômica e inclui equivocadamente outras formas de trabalhos compulsórios na categoria de escravidão.

Mas o crescimento da demanda e quantidade de escravos no período da república romana não foi somente fruto das consequências da guerra e do desenvolvimento econômico romano: com os conflitos internos entre plebeus e patrícios e a reivindicação de direitos pelos primeiros desde o século $V$ a.C., gradativamente a escravização legal do plebeu foi limitada e alguns direitos políticos e civis foram conquistados.

Diante uma classe plebeia que lutava para manter e assegurar sua liberdade frente à escravidão, e a expansão de Roma que implicava na incorporação de novos cidadãos, a demanda por escravos também se caracterizou por ser uma demanda política: necessitava-se de novos escravos para suprir uma "perda interna" ocasionada pelos movimentos plebeus de reivindicação de direitos e a gradativa desescravização destes.

Nos primórdios de Roma, apesar da presença de escravos ter sido uma realidade concreta, a mão de obra escrava ainda não era a base fundamental da economia romana. Há de se supor ainda que, como neste período a expansão romana era limitada, uma parcela significativa dos escravos provavelmente era proveniente da própria sociedade romana e de regiões vizinhas.

De acordo com Bradley (1985), após o fim da monarquia (753-509 a.C.) e a instauração da república, esta se encontrava fraca e inserida em um cenário onde Roma promovia mais guerras 


\section{artigos}

Ana Carolina Sodré Ferreira

defensivas do que agressivas. Esse tipo de guerra também implicava na aquisição de prisioneiros de guerra na condição de escravizados, mas a obtenção destes e seus usos não objetivava, à princípio, a satisfação exclusiva de necessidades econômicas (BRADLEY, 1985). Esta situação poderia explicar, por sua vez, a ausência de uma regulamentação específica sobre a escravidão no primeiro conjunto romano de leis escrito, redigido em meados do século $V$ a.C.: a sociedade romana, naquele momento, não era escravista.

Diante o panorama geral exposto, o presente artigo procurou identificar as formas de escravização presentes na Lei das Doze Tábuas a partir da análise das leis pertinente ao tema, e do contexto da sociedade romana no século $V$ a.C., com ênfase nos conflitos entre plebeus e patrícios. A análise se focou na escravização por dívidas, por delitos e pelo poder do patriarca sobre seus dependentes, procurando averiguar o alcance da teoria de Bradley (1985) de que, em um primeiro momento, a escravidão na sociedade romana não era majoritária nem possuía fins exclusivamente econômicos.

No final do trabalho, foi proposta uma reflexão sobre o papel e o lugar do escravo na sociedade romana no início da república, e uma reflexão sobre o surgimento da Lei das Doze Tábuas a partir do contexto de sua época. A análise do conjunto de leis foi feita com base na consulta à tradução presente no livro "A Lei das XII Tábuas: Fonte do Direito Público e Privado", de Sílvio Augusto de Bastos Meira.

\section{Visão geral sobre a escravidão romana}

De acordo com Bradley (1985), somente com a expansão romana a partir do século V a.C., a necessidade por escravos para o emprego em diferentes funções - principalmente nos campos - se tornou uma necessidade econômica e a sociedade romana iniciou sua passagem de sociedade servil ${ }^{1}$

\footnotetext{
1 A utilização de termos como "servo", servidão" e "sociedade servil", aplicados ao contexto romano, principalmente nos séculos iniciais de Roma, são problemáticos. Como destacou Finley (1986), "não existia nada, que saibamos, que se aproximasse dum sistema senhorial, com a sua divisão em parcelas camponesas e domínio senhorial, servos (ou <<camponeses dependentes >>) e senhor; não havia feudos, nem um sistema de <<compensações >>, nem justiça privada" (FINLEY, 1986, p. 256). Estes termos talvez sejam mais adequados se empregados no contexto da Antiguidade Tardia ou da transição desta para a Alta Idade Média se se levar em consideração o fato de que, no contexto romano, o camponês
} 


\section{artigos}

As formas de escravização presentes na Lei das Doze Tábuas (Século V a.C.)

para uma sociedade escravista. Para Joly (2005), o início da expansão neste século teria sido fruto da situação de Roma naquele momento, caracterizada pela hostilidade de populações vizinhas, apresentando, ainda, uma baixa produção agrícola; com o objetivo de conquistar terras, Roma teria dado início a sua expansão pelas regiões do e além Lácio.

A partir desta expansão militar, Roma conquistou diversos territórios e povos, sendo que uma parcela destes últimos foram escravizados, o que levou ao aumento da oferta de escravos que passaram, por sua vez, a serem vistos como mercadorias, sendo empregados em propriedades rurais e empreendimentos manufatureiros (FUNARI, 2003).

Segundo Guarinello (2006), a condição de mercadoria atribuída ao escravo na Antiguidade teria se difundido a partir do desenvolvimento comercial de algumas cidades-Estados mediterrânicas que, em decorrência do crescimento, expansão e complexificação de suas economias, bem como da obtenção, concentração e acúmulo de riquezas no interior dessas cidades-Estados, teria aumentado a demanda por escravos-mercadoria para a continuação do sistema de alta produção e venda de excedentes. Como afirma o autor: "Foi essa nova capacidade e possibilidade de produzir mais e de vender o excedente da produção que esteve na origem do crescimento da escravidão mercadoria em cidades como Atenas ou Roma" (GUARINELLO, 2006, p. 231).

Bradley (1985) defende que nos momentos iniciais da expansão romana, especificamente no início da república, a aquisição de escravizados não objetivava exclusivamente a satisfação de necessidades econômicas nem as conquistas eram motivadas exclusivamente pela aquisição de mão de obra escrava. Guerras eram travadas, por exemplo, para defender o território romano de ataques e invasões externas; a aquisição de prisioneiros de guerra, e a posterior escravização destes, era uma consequência secundária. Por outro lado, Bradley (1985) traz uma reflexão importante ao vincular a expansão de Roma com o aumento da demanda por escravos.

poderia servir um proprietário de terras sem perder sua liberdade. 


\section{artigos}

Ana Carolina Sodré Ferreira

Alguns anos antes da publicação do artigo de Bradley - "The Early Development of Slavery at Rome", em 1985 -, Moses Finley (1991) já havia questionado - em sua obra "Escravidão Antiga e Ideologia Moderna", de 1980) - a tese de que a conquista romana havia sido o único fator que havia aumentado o número de mão de obra escrava e, consequentemente, aberto espaço para o desenvolvimento de uma sociedade escravista. Para o autor, outros fatores deveriam ser levados em consideração para a explicação desta teoria.

Finley (1991) reconhecia a importância da conquista para a obtenção de escravizados, no entanto, o historiador chama a atenção para o fato das campanhas militares de conquista requisitarem um contingente humano, ou seja, soldados. Para o autor, estes soldados seriam representados por agricultores, comerciantes e trabalhadores urbanos, por exemplo; com o deslocamento da mão de obra produtiva para as linhas do exército, os trabalhos nos campos e nas cidades teriam que ser ocupados por outras pessoas: escravos. Desta forma, Finley (1991) afirma que para mobilizar e deslocar um grande contingente populacional para fins militares sem desestruturar a sociedade - em termos econômicos, principalmente -, era necessário que houvesse um outro contingente de indivíduos: neste caso, um contingente de escravos. O autor, porém, enfatiza somente o aspecto econômico da demanda por escravos, desconsiderando fatores internos e de outras esferas estruturais que influenciaram o surgimento e aumento desta demanda.

A detenção de um elevado contingente de escravos interferia nas relações de poder entre os cidadãos livres na medida em que se aprofundava a distância social, econômica e política entre cidadãos ricos e pobres com a afirmação de posições sociais e aumento de riquezas através do uso da mão de obra escrava na produção econômica, na proteção do senhor e nas práticas coercivas (GUARINELLO, 2006). Deter um escravo significava a possibilidade de enriquecimento pessoal, mas, também, de ter em seu controle uma "ferramenta" que poderia ser utilizada para a conquista de direitos e privilégios políticos e sociais: "A própria presença dos escravos tornou os ricos mais ricos e, portanto, aumentou suas forças nos embates com os cidadãos mais pobres" (GUARINELLO, 2006, p. 234). 


\section{artigos}

As formas de escravização presentes na Lei das Doze Tábuas (Século V a.C.)

O enriquecimento do cidadão rico aumentava sua influência e poder político em detrimento dos direitos e participação política dos cidadãos pobres, desprovidos dos meios de conquista e garantia de direitos e de aumento de participação e influência política. Se a elite econômica se vinculava à elite política, então os cidadãos pobres estariam excluídos de ambas e marginalizados na fruição de benefícios, privilégios e direitos provenientes das esferas econômica e política.

Desta forma, observa-se novamente o caráter político da demanda por escravos: se por um lado a escravidão era necessária para o funcionamento da economia e multiplicação de riquezas internas e individuais, por outro, ela era de vital importância para a manutenção de poder das classes dominantes em termos de detenção e monopolização de poder político e repressão a conflitos e movimentos de reivindicação provenientes das camadas pobres. Ademais, como enfatiza Guarinello (2006), os escravizados exerceram fortes influências nas estruturas social e cultural da sociedade romana uma vez que compartilhavam a mesma esfera de vida dos indivíduos livres: escravizados e cidadãos livres trabalhavam lado-a-lado compartilhando os mesmos espaços de trabalho, de vivência e de ócio.

E, por último, a afirmativa de Brandley de que haveria uma predominância de escravos no campo, também é questionável. Para Joly (2006), teria existido uma predominância de escravos no meio urbano, sendo o meio rural predominado por trabalhadores livres:

Se houve um espaço em que a escravidão efetivamente predominou, foi o urbano e não o rural [...] Do ponto de vista da agricultura, pesquisas recentes parecem confirmar a hipótese de que a exploração de terras cultiváveis em províncias do Império [...] não foi realizada por meio de latifúndios escravistas, mas sim com o recurso de trabalho camponês dependente local [...] Como o exemplo da Ásia Menor sugere, o que ocorreu sob domínio romano foi muito mais a difusão de um sistema fundiário gerido por capatazes. (JOLY, 2006, p. 68).

Joly (2006) defende a coexistência de diferentes modalidades de trabalho compulsório e a predominância de escravos no meio urbano, sendo que neste último teria existido um alto grau de hierarquização e especialização de funções, enquanto que no meio rural teria se caracterizado pela 


\section{artigos}

Ana Carolina Sodré Ferreira

presença de pequenos proprietários e pelas relações de cliente. Finley (1991) acrescenta ainda a presença de "trabalhadores assalariados" em fazendas.

Diante estes diversos e intensos debates históricos e historiográficos, pode-se dizer que no contexto do século $V$ a.C., havia presença de escravos na sociedade romana sem, no entanto, a escravidão se constituir na única modalidade de trabalho compulsório ou ser a modalidade predominante. Para os romanos, a escravidão era uma instituição social e a posse de escravizados, uma realidade presente na vida de diversos romanos. O uso da mão de obra escrava, no entanto, não obedecia a uma lógica política ou econômica sistematizada, pois naquela época a sociedade escravista romana ainda não havia se consolidado nem se encontrava em uma fase avançada de desenvolvimento uma vez que no século $V$ a.C., o império romano ainda estava em fase de construção, e, portanto, os mecanismos e estruturas necessários à implementação, manutenção e reprodução de um sistema escravista ainda eram embrionários e incertos. Além do mais, a sociedade romana do período republicano ainda ganhava seus contornos, principalmente a partir do início dos conflitos entre plebeus e patrícios.

\section{Conflitos entre plebeus e patrícios: contexto social e político do período $\operatorname{arcaico}^{2}$ (V-IV a.C.)}

Após o fim da monarquia, os patrícios estabeleceram monopólio exclusivo sobre os direitos políticos, civis e religiosos ao negá-los à plebe; como consequência, desde o século V a.C., observase conflitos entre estas duas camadas, com a reivindicação de direitos políticos e civis por parte da plebe (GUARINELLO, 2013). Diante este cenário, entre os séculos V e IV a.C., ocorreram conflitos decisivos entre o patriciado e a plebe que modificaram significativamente as estruturas social, econômica, cultural e política da sociedade romana, sendo a principal conquista, fruto desses conflitos, a extensão dos direitos políticos e civis à plebe, ainda que gradativamente.

\footnotetext{
${ }^{2}$ Tradicionalmente, a historiografia divide a república romana em três períodos, à saber: arcaica (V-IV a.C.; conflitos entre plebeus e patrícios), media (III a.C.; época das Guerras Púnicas); e tardio (133 à 31 ou 27 a.C.).
} 


\section{artigos}

As formas de escravização presentes na Lei das Doze Tábuas (Século V a.C.)

Nos primórdios da república romana, o poder político encontrava-se concentrado nas mãos dos patrícios ${ }^{3}$, sendo expresso, por exemplo, na monopolização de cargos públicos e na participação exclusiva no Senado (FUNARI, 2001). Segundo Funari (2001), somente este grupo detinha o exercício pleno dos direitos políticos e civis na sociedade romana; aqueles que não pertenciam ao patriciado, ou seja, aqueles que não faziam parte de uma aristocracia de sangue, não usufruíam plenamente os direitos políticos e civis.

A reivindicação da plebe por direitos políticos intensificou-se na medida em que uma parcela dessa camada prosperava financeiramente através das atividades comerciais (FUNARI, 2001): a riqueza gerada por esses plebeus equiparou-se à riqueza dos patrícios; em contrapartida, a igualdade em termos políticos entre estas duas camadas não se concretizou.

De um lado, havia a plebe urbana na qual uma parcela de homens havia enriquecido via produção artesanal e comércio; o enriquecimento instigará a reivindicação por direitos políticos e sociais, como o direito de voto no Senado e o casamento com patrícios (FUNARI, 2003). Do outro lado, havia a plebe rural que sofria com o endividamento que impunha a confiscação de terras e a escravidão por dívidas; em decorrência desta situação, a plebe rural reivindicava o fim da escravidão por dívidas e o direito de manter as terras conquistadas em guerras (FUNARI, 2003).

Apesar dessas diferenças, as plebes urbana e rural se uniram a partir de uma causa em comum: combate ao privilégio exclusivo de direitos políticos e civis pelos patrícios e a extensão desses direitos para toda a plebe, mas principalmente para a plebe enriquecida; a quebra do monopólio de terras pelos grandes proprietários; e luta pela liberdade ${ }^{4}$, com recusa à escravidão por dívidas ${ }^{5}$. A questão da terra foi uma das principais causas dos conflitos entre plebeus e patrícios: ao longo do

\footnotetext{
${ }^{3}$ Com o fim da monarquia, observa-se o fechamento da aristocracia, expressa na proibição do casamento entre patrícios e plebeus. O fechamento significou, também, o monopólio de poder e direitos políticos pelos patrícios.

${ }^{4}$ Neste caso, liberdade significava não ser escravo, não estando, portanto, submetido a outro.

${ }^{5}$ A escravidão por dívidas impunha, também, a perda temporária de liberdade do indivíduo escravizado bem como a perda total de seus direitos civis e políticos (FUNARI, 2003).
} 


\section{artigos}

Ana Carolina Sodré Ferreira

século IV a.C., por exemplo, a distribuição das terras conquistadas não era igualitária, havendo favorecimento em prol dos grandes proprietários (FUNARI, 2003).

Para Finley (1986), com as conquistas da plebe, a ordem patrícia teria perdido o prestígio como a classe mais prestigiosa da sociedade romana, tendo a ordem senatorial ocupado esta posição. Essa afirmação, no entanto, é questionável uma vez que a maioria dos senadores ainda continuou a ser de origem patrícia e os cargos públicos e políticos de maior relevância ainda continuaram a ser de monopólio dos patrícios.

É neste contexto de conflitos entre plebeus e patrícios que foi promulgada, em c. 450 a.C., a Lei das Doze Tábuas, que representou, pela primeira vez, a substituição do direito consuetudinário pelo direito escrito (MENDES, 2009).

\section{A Lei das Doze Tábuas: as formas de escravização existentes no início da República romana}

\subsection{Lei das Doze Tábuas: Características Gerais}

[...] gravadas em tábuas de bronze, em 450 a.C. e fixadas na plataforma (rostra) em que os oradores falavam para o povo romano, diante do Senado. O fato de ser pública foi muito importante, pois, assim, todos eram capazes de saber exatamente o que se podia ou não fazer e quais as punições previstas para os desobedientes. Por muitos séculos, as crianças deviam copiar e decorar a Lei das Doze Tábuas, tarefa difícil, mas que demonstra o valor atribuído pelos romanos ao conhecimento da lei. (FUNARI, 2001, p. 119).

Não se tem conhecimento de todo o conteúdo da Lei das Doze Tábuas em vista desta ter sobrevivido ao tempo e ao homem na forma de fragmentos. Felizmente, sabe-se os conteúdos tratados nas doze tábuas, tais como: direitos de propriedade, de posse e do patriarca; e leis que versam sobre o regulamento de casamentos, heranças, do sepultamento, dos litígios, dos julgamentos e das punições aos delitos.

Para Mendes (2009), as tábuas refletem uma sociedade agrária por possuírem artigos que versam sobre o "Direito de Propriedade; a consolidação da autoridade do chefe da família e dívidas" 


\section{artigos}

As formas de escravização presentes na Lei das Doze Tábuas (Século V a.C.)

(MENDES, 2009, p. 92), além de ter sido um "conjunto de respostas a problemas jurídicos cotidianos" (MENDES, 2009, p. 92), redigidas por um "um colégio de dez magistrados (decênviros)", possivelmente em 450 a.C. (MENDES, 2009).

Seu registro por escrito garantia o amplo acesso e consulta aos direitos dos cidadãos romanos:

Ao menos em termos legais, os cidadãos comuns podiam, portanto, recorrer dos abusos de autoridades cometidos pelos poderosos. A fixação pública de inscrições que garantissem esse direito demonstra a preocupação fundamental de dar a todos o acesso à informação de suas prerrogativas jurídicas. Esses são dois princípios basilares da cidadania: a possibilidade de recorrer do abuso e o amplo acesso à informação dos direitos. (FUNARI, 2003, p. 60).

Para Thébert (1992) e Funari (2001), a Lei das Doze Tábuas é um texto fundamental do direito romano. Mendes (2009), por sua vez, destaca os pontos negativos da lei: "A existência deste código não foi muito significativa para os plebeus, pois sua aplicação continuou vinculada e dependente da interpretação dos magistrados e tribunais" (MENDES, 2009, p. 92). Porém, a historiadora reconhece que a "codificaçãa, a secularização e a publicação do Direito foram decisivas para a unificação da comunidade" (MENDES, 2009, p. 92). Funari (2003) também analisa a redação das tábuas de forma negativa e positiva, destacando a reafirmação dos poderes dos patrícios e os benefícios adquiridos pela plebe enriquecida:

Embora fosse a codificação da legislação tradicional, que previa grande poder aos patriarcas, estabeleceu-se ali o importante princípio da lei escrita. De fato, o chamado direito consuetudinário, baseado na tradição, gerava grande insegurança

- já que, em caso de divergência, a palavra final era sempre dos patrícios. Com a publicação da lei, todos podiam recorrer a um texto conhecido para reclamar direitos sem depender da boa vontade dos poderosos. Instituiu-se também a classificação das pessoas pelas posses. Isso beneficiou os plebeus ricos, cuja importância social começou a ser reconhecida. (FUNARI, 2003, p. 53).

\subsection{A Lei das Doze Tábuas: Formas de Escravização}




\section{artigos}

Ana Carolina Sodré Ferreira

A primeira menção ao escravo e à sua forma de escravização ocorre na segunda tábua, que trata das questões referentes aos delitos e seus respectivos julgamentos e punições: "4. Se o furto ocorre durante o dia e o ladrão é flagrado, que seja fustigado e entregue como escravo à vítima. Se é escravo, que seja fustigado e precipitado do alto da rocha Tarpéia" (MEIRA, p. 168). De forma geral, as punições para os delitos de furto previstas na tábua, em suas diferentes situações, são rigorosas e violentas; de fato, a violência é uma constante no conteúdo das doze tábuas, não sendo rara a presença de punições físicas e de sentenças de morte.

Na citação transcrita acima, a escravização daquele que furta ocorre somente se este for pego em flagrante e durante o dia; e, certamente, o infrator somente será escravizado se estiver em condição contrária a esta, ou seja, se for livre. O artigo não determina se há um período mínimo ou máximo para a condição de escravizado do infrator, sugerindo, assim, que a vítima do furto possuía direito de posse sobre o infrator por tempo indeterminado, podendo dispor de seu escravizado da forma que lhe aprouvesse. $O$ artigo também não especifica se a escravização se referia a cidadãos e/ou não cidadãos. Por fim, se o infrator já fosse um escravo, então sua sentença seria o açoite seguido de morte.

Neste caso, observa-se que a escravização se dá em um contexto interno e refere-se a um indivíduo livre, podendo este ser ou não um cidadão; em outras palavras, a escravização de um indivíduo e sua consequente aquisição por outro, não se deu em um contexto de guerra a partir da escravização dos vencidos (estrangeiros). Logo, a escravização presente neste artigo não foi proveniente de uma necessidade econômica, e, sim, de uma necessidade de punição a um delito cometido e de reparação à vítima, que poderia usar ou não o infrator escravizado para fins econômicos. Soma-se a esta realidade o fato de sentenciar-se à morte o escravo que cometia furtos e pode-se questionar o lugar e a importância do escravo na economia romana daquela época.

Porém, podemos, também, questionar as motivações por detrás da punição. Se o contexto da época era de conflitos e monopolização de terras pelos patrícios - ou seja, monopolização dos meios de subsistência e geração de excedentes -, pode-se supor a existência de um quadro de violência e pobreza entre as camadas pobres que teria levado a ações como as de roubo e furto. A punição de 


\section{artigos}

\section{As formas de escravização presentes na Lei das Doze Tábuas (Século $\vee$ a.C.)}

escravização aplicada nesses casos seria uma forma de beneficiar as classes dominantes? Se assim o tenha sido, ainda não há como afirmar que essa punição tenha sido fruto de uma necessidade estritamente econômica, mas ela fornece indícios de possíveis interesses em se adquirir indivíduos escravizados por tempo indeterminado.

Se naquele momento o escravo fosse elemento fundamental na estrutura econômica como o fora alguns séculos mais tarde no período imperial, a imposição de sentenças de mortes ao escravizado não seria mais prejudicial do que benéfico à estrutura econômica da sociedade romana? No trecho a seguir, podemos vislumbrar novamente o questionamento levantado:

TÁBUA TERCEIRA

Dos direitos de crédito

[...] 4. Aquêle que confessa dívida perante o magistrado ou é condenado, terá 30 dias para pagar.

5. Esgotados os 30 dias e não tendo pago, que seja agarrado e levado à presença do magistrado.

6. Se não paga e ninguém se apresenta como fiador, que o devedor seja levado pelo seu credor e amarrado pelo pescoço e pés com cadeias com pêso até o máximo de 15 libras; ou menos, se assim o quiser o credor.

7. O devedor prêso viverá à sua custa, se quiser; se não quiser, o credor que o mantém prêso dar-Ihe-á por dia uma libra de pão ou mais, a seu critério.

9. Se não há conciliação, que o devedor fique prêso por 60 dias, durante os quais será conduzido em 3 dias de feira ao comitium, onde se proclamará, em altas vozes, o valor da dívida.

9. Se são muitos os credores, é permitido, depois do terceiro dia de feira, dividir o corpo do devedor em tantos pedaços quantos sejam os credores, não importando 


\section{artigos}

Ana Carolina Sodré Ferreira

cortar mais ou menos; se os credores preferirem, poderão vender o devedor a um estrangeiro, além do Tibre. (MEIRA, p. 169).

Na terceira tábua, as leis versam sobre os casos de inadimplência, havendo uma série de artigos que tratam do procedimento da escravidão por dívidas, como evidenciado na transcrição acima. Desta vez, a escravização é fruto de um contexto de transações financeiras.

Em um primeiro momento, o devedor é intimado perante um magistrado, recebendo um período de 30 dias para quitar sua dívida; caso não cumpra esta determinação, o credor poderá leválo consigo ("prisão"). Apesar de os artigos não especificarem, neste segundo momento, o devedor aparenta se encontrar no meio do processo de conversão à escravidão: ele perde sua liberdade, porém, não pertence definitivamente ao seu credor, pois ainda dispõe de um período de 60 dias para quitar sua dívida ou entrar em um outro tipo de acordo com seu credor. Por fim, passados os 60 dias, o credor adquirirá a posse definitiva de seu devedor, podendo vendê-lo como escravo a um estrangeiro além do Tibre ou esquartejá-lo e dividir seus pedaços entre outros credores, se for o caso.

Esta segunda forma de escravização, aparentemente não parece ser motivada por necessidades e interesses econômicos uma vez que, novamente, a lei prevê a sentença de morte em relação ao escravo e visa a reparação de dano ao lesado (neste caso, o credor). Diferentemente da segunda tábua, nesta terceira, fica explícita a condição de mercadoria agregada ao escravo, pois este poderia ser vendido.

Entretanto, nos conflitos entre plebeus e patrícios, havia uma forte reivindicação pelo fim da escravidão por dívidas, o que sugere, portanto, que o credor optava por manter o devedor na condição de escravizado ao invés de matá-lo, indicando, assim, a importância que a escravização por dívidas havia adquirido na sociedade romana em épocas anteriores à promulgação das tábuas.

Se a Lei das Doze Tábuas carece de uma legislação específica para a escravidão e as formas de escravização, a terceira tábua dedica uma especial atenção e detalhamento à escravização por dívidas. Esse enfoque pode indicar a importância que essa modalidade de escravização havia 


\section{artigos}

As formas de escravização presentes na Lei das Doze Tábuas (Século V a.C.)

adquirido até então, principalmente em um momento no qual os plebeus perdiam suas terras aos grandes proprietários e, assim, se viam desprovidos de meios para se sustentarem e gerarem renda para pagarem suas dívidas e adquirirem bens.

Desta forma, a tábua sugere a existência de uma prática de escravização que ganhava contornos de uma espécie de sistema escravista centrado na escravidão por dívidas. Ao mesmo tempo, se a terceira tábua aponta para uma crescente escravização presente no interior da sociedade romana, ela também aponta para uma significativa existência de indivíduos desprovidos de direitos políticos e civis que os protegessem de serem escravizados. Ou seja, se naquele momento havia interesses ou demandas por escravos, elas eram facilitadas e até mesmo motivadas pela realidade política da época, de monopolização de poderes e direitos políticos e civis pelos patrícios em detrimento dos plebeus.

Por fim, a terceira forma de escravização presente na Lei das Doze Tábuas se dá em âmbito doméstico sob o poder do patriarca da família:

TÁBUA QUARTA

Do pátrio poder e do casamento

[...] 2. O pai terá sôbre os filhos nascidos de casamento legítimo o direito de vida e de morte e o poder de vendê-los.

3. Se o pai vendeu o filho 3 vêzes, que êsse filho não recaia mais sob o poder paterno [...] (MEIRA, p. 169).

Em função do fato da sociedade romana ter sido uma sociedade patriarcal, um grande poder se concentrava nas mãos do pai (homem): no âmbito público, o homem detinha o poder político (à princípio, homens patrícios e, posteriormente, homens plebeus também); no âmbito doméstico, tinha em sua dependência e poder os escravos, os agregados, a esposa e os filhos, possuindo o direito de vida e morte sobre estes últimos, o que incluía o direito de vendê-los. 


\section{artigos}

Ana Carolina Sodré Ferreira

Nesta quarta tábua, a forma de escravização emana de um direito paterno-patriarcal, onde o pai poderia dispor dos filhos em condição de mercadoria a ser vendida e revendida, ainda que de forma limitada: o fato de haver um limite de venda de três vezes sugere que os filhos não eram vendidos definitivamente e, sim, "alugados" por tempo determinado. Pode-se supor, desta forma, que os filhos poderiam ser alugados ou penhorados para saldar uma dívida ou para se obter uma renda financeira. Diferentemente das outras duas formas de escravização, esta se apresenta mais próxima dos interesses econômicos por deixar explícito a condição de mercadoria do filho-escravo.

Ao contrário das tábuas analisadas anteriormente, a forma de escravização presente nesta beneficia, também, as camadas pobres: sem terras e sem bens, os indivíduos pobres poderiam se livrar de dívidas e obter rendas financeiras a partir do uso monetizado da mão de obra de seus filhos. Podemos supor que o pai, por exemplo, poderia "emprestar" seu filho a um credor até quitar a dívida aberta para ele próprio não ser escravizado - a segunda tábua permitia que o devedor e o credor chegassem a um acordo comum para saldar a dívida; além do mais, como sugere o contexto da época, a necessidade ou interesse de se obter escravizados, favorecia as relações comerciais de se alugar a mão de obra de um filho junto ao seu pai. Por essas características, não parece adequado caracterizar essa relação como uma forma de escravização, mas, sim, como um outro tipo de trabalho compulsório diferente da escravidão - ainda que o filho fosse tratado como um escravo -, principalmente pela tábua não classificar juridicamente essa relação como tal.

Não obstante, a igualação entre escravo e filho-escravo só deve ser feita em termos de mercadoria humana. Com a Lei das Doze Tábuas, as relações de subordinação entre patriarca-filho e patriarca-escravo adquiriram semelhanças do ponto de vista econômico: da mesma forma que o patriarca podia vender seus escravos, ele também podia vender - neste caso, alugar - seus filhos. Logo, escravos e filhos "livres" dos patriarcas constituíam-se em mercadorias. Todavia, a equidade dessas duas relações encontra-se somente na possibilidade de conversão à mercadoria tanto do escravo como do filho. Ademais, o filho estava destinado a se tornar um cidadão e o patriarca de uma família - o que pode explicar a limitação de "venda" do filho pelo pai, impedindo que este se desfizesse de seus herdeiros e futuros cidadãos romanos via escravização -, ao passo que o escravo 


\section{artigos}

As formas de escravização presentes na Lei das Doze Tábuas (Século V a.C.)

continuava a ser destinado à escravidão, podendo ocorrer a possibilidade ou não da conquista ou compra de sua própria liberdade (THÉBERT, 1992).

A análise da quarta tábua, no entanto, ainda é pertinente à análise das formas de escravização presente nas Leis das Doze Tábuas porque ilustra como a escravidão e os trabalhos compulsórios assemelhavam-se, chegando a confundir-se, mas eram diferenciados por definições jurídicas explícitas ou não. O próprio poder de "venda" que o pai possuía sobre filho é pertinente para questionar a concepção de escravidão, liberdade e cidadania dos romanos do início da república.

\section{Considerações finais}

A Lei das Doze Tábuas foi a primeira lei a ser registrada por escrito, tendo garantido o conhecimento e a consulta das leis por toda a população romana - plebeus e patrícios - de forma que, pelo menos em tese, não houvesse abuso de poder, exploração e arbitrariedade por parte do patriciado em relação à plebe. Esta conquista, no entanto, não garantiu a conquista de leis favoráveis à plebe: a escravidão por dívidas foi afirmada, a proibição de casamento entre patrícios e plebeus mantida, e o julgamento de casos e designações de arbitrários em litígios continuavam a ser de encargo de homens que ocupavam cargos destinados exclusivamente a patrícios.

Apesar das tábuas fazerem menção ao escravo - de forma dispersa -, não há nelas, porém, uma regulamentação específica sobre a escravidão. Para Bradley (1985), a inexistência de uma lei específica para a escravidão no conjunto da Lei das Doze Tábuas sugere uma suposta predominância da "servidão" - outras formas de trabalho compulsório - em detrimento da escravidão no contexto romano do século $\mathrm{V}$ a.C.

Além do mais, o conteúdo da Lei das Doze Tábuas não se mostra inovador uma vez que se baseou no direito consuetudinário, ou seja, em costumes que já eram praticados antes de seus registros por escrito (BRADLEY, 1985). Em vista deste fato, as leis não refletiam necessariamente e tão somente a realidade do século $V$ a.C., podendo, ao invés disso, expressar uma realidade anterior a este século, onde a existência de escravos e a presença destes nas diferentes estruturas da sociedade era uma realidade, explicando, assim, a menção de escravos nas leis, mas não o 


\section{artigos}

Ana Carolina Sodré Ferreira

desenvolvimento de uma lei específica que regulamentasse uma escravidão que não era o motor de funcionamento de uma sociedade que ainda não era escravista (BRADLEY, 1985).

A presença escrava na sociedade romana remonta ao período monárquico. Considerando a Lei das Doze Tábuas como um reflexo dos costumes praticados desde antes do século $\mathrm{V}$ a.C., certamente a escravidão interna (de cidadãos e não-cidadãos, filhos e indivíduos livres) e a externa (prisioneiros de guerra) compunham a realidade romana desde o princípio. A contestação das leis presentes nas tábuas aponta para uma mudança que estava em curso na sociedade romana - contestação da forte exploração da plebe romana via escravização e negação de direitos políticos e civil por uma minoria patrícia -, tendo sido originada nos conflitos entre plebeus e patrícios, e acentuada, por sua vez, pela expansão romana que havia imposto uma reordenação das dinâmicas internas da sociedade romana em suas diferentes esferas: social, econômica, cultural e política.

A reivindicação de cidadania pelos plebeus na sociedade romana se opunha a escravização de seus membros internos, o que pode ter contribuindo para a demanda por escravos provenientes de fora da sociedade romana como forma de compensar essa perda, que impunha uma outra forma de escravização que não a interna.

Ao mesmo tempo em que a Lei das Doze Tábuas nos revela a permanência de costumes passados, ela também revela - a partir da contestação a ela - o desejo de mudança desses costumes por uma plebe desejosa de direitos políticos e civis e proteção contra explorações que viessem a lhe excluir das riquezas provenientes de uma Roma que começava a se expandir e constituir-se em um Estado forte e próspero. Ora, o próprio conjunto de leis representa uma mudança ao marcar a transição do direito consuetudinário para o direito escrito. A contestação a esse conjunto não demorou a acontecer: em 445 a.C., fora aprovada a Lei Canuleia que permitia o casamento entre patrícios e plebeus, o que pôs à proibição desse tipo de casamento prevista, até então, pela Lei das Doze Tábuas.

No que concerne as formas de escravização presentes nas tábuas, podemos supor que até, pelo menos, o século $V$ a.C., a escravização não era orientada primordialmente pelas necessidades e 


\section{artigos}

As formas de escravização presentes na Lei das Doze Tábuas (Século V a.C.)

interesses econômicos - embora estes fatores já apareçam nas leis, se constituindo em um esboço de uma nova realidade que começava a se fundamentar no escravo-mercadoria -, podendo ser fruto, também, dos direitos paterno, jurídico e financeiro, sendo que a utilização da mão de obra escrava poderia assumir finalidades diversas, não limitando-se somente a finalidades econômicas. O contexto de conflitos entre plebeus e patrícios e suas consequências no pós-século IV a.C., servem para nos revelar as implicações políticas e sociais por detrás do crescimento e uso da mão de obra escrava na economia e sociedade romana, apontando, portanto, que a sociedade escravista estabelecida não foi fruto somente de interesses e necessidades econômicas, mas foi, também, uma reação e resposta a demandas políticas e sociais internas.

\section{Referências Bibliográficas}

BRADLEY, Keith R.. The Early Development of Slavery at Rome. Historical Reflections / Réflexions Historiques, New York, v. 12, n. 1, p.1-8, mar. 1985. Published by: Berghahn Books. Disponível em: <http://www.jstor.org/stable/41298844>. Acesso em: 4 nov. 2017.

FINLEY, Moses I. Ordens e Status. In: FINLEY, Moses I. A Economia Antiga. 2. ed. Porto: Afrontamento, 1986. Cap. 2. p. 45-81.

Reflexões Adicionais: Classe e status, trabalho livre e não livre. In: FINLEY, Moses I. A Economia

Antiga. 2. ed. Porto: Afrontamento, 1986. Cap. 7. p. 243-289.

O Surgimento de uma Sociedade Escravista. In: FINLEY, Moses I. Escravidão Antiga e Ideologia Moderna. Rio de Janeiro: Graal, 1991. Cap. 2. p. 69-95. Tradução de: Norberto Luiz Guarinello.

FUNARI, Pedro Paulo Abreu. A cidadania entre os romanos. In: PINSKY, Jaime; PINSKY, Carla Bassanezi (Org.). História da Cidadania. São Paulo: Contexto, 2003, p. 49-73.

Roma. In: FUNARI, Pedro Paulo. Grécia e Roma. São Paulo: Editora Contexto, 2001. p. 77-134. 


\section{artigos}

Ana Carolina Sodré Ferreira

GARRAFFONI, Renata Senna. Guerras Púnicas. In: MAGNOLI, Demétrio (org). História das Guerras. 4. ed. São Paulo: Contexto, 2008, p. 47-76.

GUARINELLO, Norberto Luiz. Hegemonias. In: GUARINELLO, Norberto Luiz. História Antiga. São Paulo: Editora Contexto, 2013. p. 97-126.

Escravos sem senhores: escravidão, trabalho e poder no mundo romano. Revista Brasileira de História, São Paulo, v. 26, n. 52, p. 227-246, Dec. 2006. Disponível em: <http://www.scielo.br/scielo.php?script=sci arttext\&pid=S0102-01882006000200010>. Acesso em: 04 nov. 2017.

JOLY, Fábio Duarte. A escravidão na Roma antiga: Política, economia e cultura. São Paulo: Alameda, 2005.

Terra e Trabalho na Itália no Alto Império. In: SILVA, Gilvan Ventura; MENDES, Norma Musco. Repensando o Império Romano: Perspectiva socioeconômica, política e cultural. Rio de Janeiro: Mauad; Vitória-ES: EDUFES, 2006, p. 65-83.

MEIRA, Sílvio Augusto de Bastos. A Lei das XII Tábuas: Fonte do Direito Público e Privado. 3. ed. Rio de Janeiro: Forense.

MENDES, Norma Musco. Política e Identidade em Roma Republicana. In: FUNARI, Pedro Paulo Abreu (org); SILVA, Maria Aparecida de Oliveira (org). Política e Identidades no Mundo Antigo. São Paulo: Annablume, 2009. p. 87-106. (Coleção: História e Arqueologia em Movimento).

THÉBERT, Yvon. O Escravo. In: GIARDINA, Andrea (dir). O Homem Romano. Lisboa: Editorial Presença, 1992. p. 117-145. Tradução de: Maria Jorge Vilar de Figueiredo. 